\title{
Knowledge and Practice of Safety Measures against Hazards among Footwear Manufacturers in Jos, Plateau State
}

\author{
Yetunde Olubusayo Tagurum ${ }^{1}$, Isaac Ebije Ochekwu ${ }^{2}$, \\ Fwangkat Katfwang Daburuk ${ }^{2}$, Solomon Obiwanne Nwaiwu², \\ Mathilda Edmund Banwat ${ }^{1}$ \\ ${ }^{1}$ Department of Community Medicine, Faculty of Clinical Sciences, College of Health Sciences, University of \\ Jos, Nigeria. \\ ${ }^{2}$ Department of Medicine, Faculty of Clinical Sciences, College of Health Sciences, University of Jos
}

Corresponding Author: Yetunde Olubusayo Tagurum

\begin{abstract}
Background: Footwear manufacturing is among the oldest traditional occupations. As with other occupations, they are prone to workplace hazards which can be physical, chemical, biological, mechanical and/or psychosocial. Persons involved in shoe manufacturing are prone to exposure to a lot of leather, rubber, and textile dust. Other dust generating tasks include skiving and cutting operations. The aim of this study was to determine the knowledge and practice of safety measures against hazards among footwear manufacturers in Jos, Plateau State, Nigeria.

Methodology: It was a cross-sectional study which involved using semi-structured intervieweradministered questionnaires to obtain information from 146 footwear manufacturers. A cluster sampling technique was employed for selection of respondents. Data was analyzed using EPI-Info® version 3.5.4 statistical software package and a p-value of $<0.05$ was considered as statistically significant for the study.

Results: The response rate of the respondents was $100 \%$ with majority of the respondents between ages 20-30 years. Most of the respondents, 91 (62.8\%) had a fair knowledge of safety measures while $80(55.2 \%)$ had fair practice of safety measures. There was a statistically significant relationship between the level of education and their knowledge of safety measures ( $\mathrm{P}$ - value of 0.0071). There was also a statistically significant relationship between the age group and their practice of safety measures $(\mathrm{P}-$ value $=0.0127)$.

Conclusion: This study concludes that there is need for increased enlightenment on work hazards among footwear manufacturers and the need for government intervention in order to set up safety trainings, subsidize safety equipment and provide incentives.
\end{abstract}

Key Words: Footwear manufacturers, knowledge, safety practice, occupational hazards, occupational health problems, PPE

\section{INTRODUCTION}

Footwear manufacturing is among the oldest traditional occupations. As with other occupations, they are prone to workplace hazards which can be physical, chemical, biological, mechanical and/or psychosocial. Persons involved in shoe manufacturing are prone to exposure to a lot of leather, rubber, and textile dust. Other dust generating tasks include skiving and cutting operations. Any dust exposure is hazardous as dust can irritate or damage workers' lungs and upper airways. ${ }^{1}$

Hazardous chemical substances such as adhesives containing benzene and toluene are used in the manufacturing process. $^{2 .}$ 
These adhesives are usually highly flammable and tend to result in fire hazards. The use of sharp, grinding instruments in the production process is also associated with a lot of hand injuries. ${ }^{3}$ The loud noises from machines used is another hazard which usually exert detrimental aural effects. ${ }^{1}$

Global epidemiological studies provide evidence that employment in shoe production and repair is associated with an enhanced risk for cancer (primarily nose and nasal sinuses). According to the majority of findings, these types of cancers are induced by exposure to leather dust. Leather dust particles contain numerous chemicals acquired during the process of leather tanning and finishing and some of these compounds exert carcinogenic effect. In fact, among the occupational causes of sinonasal cancer, the International Agency for Research into Cancer (IARC) has implicated the manufacture and repair of leather goods as a leading employment category for contact with hazardous contaminants. ${ }^{4}$ Furthermore, the IARC asserts that because there is less scientific consensus on the carcinogenic effect of fumes and dusts from the repairing process, proper preventive measures have not been implemented by many workplaces thus workers are not adequately protected against this health risk. But cancer is not the only threat as they are prone to other skin infections like dermatitis due to direct contact with these chemical substances. Electron-microscopic studies showed that the airborne dust samples collected during the machine repair of shoes contained leather, polymers, and finishing materials. And within a variety of common shoe repair and refinishing products, two major chemicals, heptane and ethanol, often can be found. ${ }^{4}$

Employees in the shoe manufacturing industry are routinely exposed to a mixture of organic solvents used in cleaning and as diluents in glues, primers, and degreasers. Exposure to organic solvents in shoe factories has been reported to increase the risks for acute and chronic health problems in shoe-makers. ${ }^{5} \mathrm{~A}$ common route of exposure to these chemicals in shoe repair facilities, is through the inhalation of vapor and mist. ${ }^{6}$ Cobblers are also not left out as they also utilize the same chemical substances and instruments for their work process.

As latest fashion trends keep on unfolding, there will be constant need for their services and this invariably translates to continuous and prolonged exposure to these hazardous chemical substances. Hence the need for safety measures cannot be overemphasized. Safety measures such as the use of protective clothing, rotation of the work process, the use of enclosures to limit noise, use of a local exhaust system, use of safer and non-toxic solvents will go a long way to mitigate the short- and long-term effect of hazards associated with the work process. The challenge remains the level of knowledge and practice by industry players. This study was therefore conducted to determine the knowledge and practice of safety measures against hazards among footwear manufacturers in Jos, Plateau State.

\section{METHODS}

The study was carried out in Jos metropolis of Plateau State. Jos metropolis encompasses Jos North, Jos South and Jos East local government areas (LGA) of Plateau State. The number of footwear manufacturers is estimated to be about 600 and they are scattered around the city. They are more concentrated around Tudun Wada, Angwan Rukuba, Bukuru, Dadin Kowa and Naraguta villages. They engage in the production of different types of footwear such as 'brogues', oxfords, toms, loafers, Ankara branded shoes etc. Depending on the type of customer and level of demand, they usually engage in production of a unit or mass production. A cross sectional descriptive study design was employed for the study using a prevalence rate of $16.6 \%$ (Prevalence of carpal tunnel syndrome in a large footwear factory in Indonesia) ${ }^{7}$ an absolute standard error of 0.05 and a 
standard normal deviate of 1.96 , a minimum sample size of 146 was calculated using the formula for cross sectional study.

A cluster sampling technique was used to select respondents. From the list of villages where the footwear manufacturers were concentrated, simple random sampling technique by balloting was used to select three villages and these villages were studied as clusters. Informed verbal consent was obtained from each respondent before being enrolled into the study; after being assured of confidentiality and anonymity without any loss of benefits or penalty. A semi-structured interviewer-administered questionnaire was used for data collection and was divided into: Section A: Sociodemographic data, Section B: Occupational data, Section C: Knowledge of safety measures, Section D: Practice of safety measures.

Responses were scored and graded appropriately into good, fair or poor for each of the respondents. For every correct answer the respondent gets a score of one and for every wrong or blank the respondent gets a zero. For the section on knowledge of safety measures (with a total score of 32): a score between $0-10$ was graded as poor knowledge, a score of 11-21 was graded as poor knowledge while a score of 22-32 was graded as good knowledge. Also, for the section of practice of safety measures (with a total score of 8), score between 0-2 was graded as poor, a score of 3-5 was graded as fair while a score of 6-8 was graded as good practice.

The data collected was analyzed using Epi-info software version 3.5.4 and quantitative data were presented using means and standard deviation while qualitative data was presented using frequency tables, percentages and charts. Tests of statistically significant relationships were carried out using Chi-square test. A probability values of $\leq 0.05$ was considered statistically significant.

\section{RESULTS}

A total of 146 respondents participated in this study. The age range of respondents was between 13 and 42 years with a mean age of $24.2 \pm 6.1$ years and the highest proportion of respondents, 129 (43.7\%) were aged 20 - 30 years. A larger proportion were single, $122(83.6 \%)$ and almost half of them had secondary education, $72(49.3 \%)$ while only $2(1.4 \%)$ had no education at all. (Table 1)

Table 1: Sociodemographic characteristics of respondents

\begin{tabular}{|l|c|c|}
\hline VARIABLES & $\begin{array}{c}\text { FREQUENCY } \\
\text { (N=146) }\end{array}$ & PERCENTAGE \\
\hline Age group (years) & 52 & 35.6 \\
$10-19$ & 77 & 52.0 \\
$20-29$ & 15 & 10.3 \\
$30-39$ & 2 & 1.4 \\
$40-49$ & & \\
Mean=24.2 \pm 6.1 & & \\
Range=13-42 & 2 & 1.4 \\
\hline Level of Education & 26 & 17.8 \\
None & 72 & 49.3 \\
Completed Primary & 21 & 14.4 \\
Completed Secondary & 26 & 17.1 \\
Completed Diploma & & \\
Bachelor's degree & 119 & 81.5 \\
Religion & 27 & 18.5 \\
Christianity & 122 & 83.6 \\
Islam & 19 & 13.0 \\
\hline Marital Status & 5.4 \\
Single & 5 & \\
Married & & \\
Divorced & & \\
\hline
\end{tabular}

Table 2: Occupational data of Respondents

\begin{tabular}{|l|c|c|}
\hline VARIABLES & $\begin{array}{l}\text { FREQUENCY } \\
(\mathbf{N = 1 4 6})\end{array}$ & $\begin{array}{l}\text { PERCENTAGE } \\
(\%)\end{array}$ \\
\hline $\begin{array}{l}\text { Duration of work (years) } \\
<10\end{array}$ & 110 & 75.3 \\
$>10$ & 36 & 24.7 \\
Mean=24.2 \pm 6.1 & & \\
\hline Number of hours worked & & \\
per day & 61 & 41.8 \\
$<8$ & 85 & 58.2 \\
$>8$ & & \\
\hline Employment Pattern & 123 & 84.2 \\
Full time & 23 & 15.8 \\
Part time & & \\
\hline
\end{tabular}

One hundred and ten (65.8\%) respondents had been involved in the occupation for less than 10 years while majority $123(84.2 \%)$ worked full time.

The study revealed that $121(82.9 \%)$ of the respondents were aware of the adverse effect of work on health. One hundred and forty $(95 \%)$ of the respondents knew of hazards associated with their work. Of the respondents, $89(61 \%)$ were not aware of diseases associated with the hazards. One hundred and forty-two 
Yetunde Olubusayo Tagurum et.al. Knowledge and practice of safety measures against hazards among footwear manufacturers in Jos, Plateau State.

$(97.3 \%)$ respondents knew of safety measures against occupational hazards. More than half of the respondents, 90 $(61.6 \%)$ were aware of the negative effect of glues and chemicals used during their work process. Eighty-eight $(60.3 \%)$ respondents were aware of the positive effect of handwashing, $129(88.4 \%)$ of the respondents were aware of the use of personal protection during their work process. One hundred and twenty $(82.2 \%)$ of the respondents knew the importance of regular hospital checkups. Most of the respondents, $91(62.8 \%)$ had a fair knowledge grade. Only $7(4.8 \%)$ had a good knowledge grade. (Table 3)

Table 3: Knowledge of Safety Measures of the Respondents

\begin{tabular}{|c|c|c|}
\hline VARIABLES & FREQUENCY(N=146) & PERCENTAGE (\%) \\
\hline $\begin{array}{l}\text { Awareness of negative effect of work on health } \\
\text { Yes } \\
\text { No }\end{array}$ & $\begin{array}{c}121 \\
25\end{array}$ & $\begin{array}{l}82.9 \\
17.1\end{array}$ \\
\hline $\begin{array}{l}\text { Awareness of work hazards } \\
\text { Yes } \\
\text { No }\end{array}$ & $\begin{array}{c}140 \\
6\end{array}$ & $\begin{array}{c}95.9 \\
4.1\end{array}$ \\
\hline $\begin{array}{l}\text { Awareness of diseases caused by exposure to these hazards } \\
\text { Yes } \\
\text { No }\end{array}$ & $\begin{array}{l}57 \\
89\end{array}$ & $\begin{array}{l}39.0 \\
61.0\end{array}$ \\
\hline $\begin{array}{l}\text { Awareness of any safety measures in the workplace } \\
\text { Yes } \\
\text { No }\end{array}$ & $\begin{array}{c}142 \\
4\end{array}$ & $\begin{array}{c}97.3 \\
2.7\end{array}$ \\
\hline $\begin{array}{l}\text { Awareness of the harmful effects of glues and chemicals } \\
\text { Yes } \\
\text { No }\end{array}$ & $\begin{array}{l}90 \\
56 \\
\end{array}$ & $\begin{array}{l}61.6 \\
38.4 \\
\end{array}$ \\
\hline $\begin{array}{l}\text { Awareness of the Positive effect of Handwashing } \\
\text { Yes } \\
\text { No }\end{array}$ & $\begin{array}{l}88 \\
58 \\
\end{array}$ & $\begin{array}{l}60.3 \\
39.7 \\
\end{array}$ \\
\hline $\begin{array}{l}\text { Awareness of the importance of wearing PPE during work } \\
\text { Yes } \\
\text { No }\end{array}$ & $\begin{array}{c}129 \\
17\end{array}$ & $\begin{array}{l}88.4 \\
11.6\end{array}$ \\
\hline $\begin{array}{l}\text { Awareness of The Importance of Periodic medical Checkup. } \\
\text { Yes } \\
\text { No }\end{array}$ & $\begin{array}{c}120 \\
26\end{array}$ & $\begin{array}{l}82.2 \\
17.8\end{array}$ \\
\hline $\begin{array}{l}\text { Awareness of specific hazards } \\
\text { Dust } \\
\text { Needle pricks/injuries } \\
\text { Noise } \\
\text { Long working hours } \\
\text { Vibrations } \\
\text { Heavy lifting } \\
\text { Gaseous fumes } \\
\text { Heat }\end{array}$ & $\begin{array}{c}128 \\
41 \\
40 \\
30 \\
12 \\
8 \\
7 \\
4\end{array}$ & $\begin{array}{c}87.7 \\
28.1 \\
27.4 \\
20.5 \\
8.2 \\
5.5 \\
4.8 \\
2.7\end{array}$ \\
\hline $\begin{array}{l}\text { Awareness of specific safety measures } \\
\text { Facemask/Shield } \\
\text { Goggles } \\
\text { soap and water } \\
\text { Good ventilation } \\
\text { Gloves } \\
\text { Boots } \\
\text { Earplug } \\
\text { Medical Examinations } \\
\text { Environmental Monitoring } \\
\text { Standard Operating Procedures } \\
\text { Safety Trainings }\end{array}$ & $\begin{array}{c}120 \\
71 \\
41 \\
27 \\
16 \\
12 \\
8 \\
4 \\
4 \\
3 \\
3 \\
\end{array}$ & $\begin{array}{c}82.2 \\
48.6 \\
28.1 \\
18.5 \\
11.0 \\
8.2 \\
4.5 \\
2.7 \\
2.7 \\
2.1 \\
2.1 \\
\end{array}$ \\
\hline $\begin{array}{l}\text { Knowledge Grade } \\
\text { Good } \\
\text { Fair } \\
\text { Poor }\end{array}$ & $\begin{array}{l}7 \\
91 \\
47\end{array}$ & $\begin{array}{c}4.8 \\
62.8 \\
32.4 \\
\end{array}$ \\
\hline
\end{tabular}

The study also revealed that 123 (84.2\%) respondents used face masks during work. One hundred and five (71.9\%) respondents practiced regular handwashing after work. Of the respondents, 127 (87.6\%) of them did not use gloves when working with glues. One hundred and forty-four (78.1\%) respondents did not use ear plugs when working with loud machines. Most of the respondents, $119(81.5 \%)$ did not go for regular hospital checkups. One hundred and thirty-four $(91.8 \%)$ respondents did not have 
Yetunde Olubusayo Tagurum et.al. Knowledge and practice of safety measures against hazards among footwear manufacturers in Jos, Plateau State.

first aid boxes in their workspaces, while 77 $(52.7 \%)$ respondents used goggles when filing. Most of the respondents, 80 (55.2\%)

thus had a fair safety practice grade. Only $14(9.7 \%)$ had a good knowledge grade. (Table 5).

Table 5: Practice of safety measures among respondents

\begin{tabular}{|c|c|c|}
\hline VARIABLES & FREQUENCY(N=146) & PERCENTAGE (\%) \\
\hline $\begin{array}{l}\text { Use of face mask at work } \\
\text { Yes } \\
\text { No }\end{array}$ & $\begin{array}{c}123 \\
23\end{array}$ & $\begin{array}{l}84.2 \\
15.8\end{array}$ \\
\hline $\begin{array}{l}\text { Practice of hand washing after work } \\
\text { Yes } \\
\text { No }\end{array}$ & $\begin{array}{c}105 \\
41 \\
\end{array}$ & $\begin{array}{l}71.9 \\
28.1 \\
\end{array}$ \\
\hline $\begin{array}{l}\text { Use of Gloves When Working with Glues } \\
\text { Yes } \\
\text { No }\end{array}$ & $\begin{array}{c}18 \\
127 \\
\end{array}$ & $\begin{array}{l}12.4 \\
87.6\end{array}$ \\
\hline $\begin{array}{l}\text { Use of ear plugs when working on loud machines } \\
\text { Yes } \\
\text { No }\end{array}$ & $\begin{array}{c}32 \\
144\end{array}$ & $\begin{array}{l}21.9 \\
78.1\end{array}$ \\
\hline $\begin{array}{l}\text { Going for Regular Hospital Checkups } \\
\text { Yes } \\
\text { No }\end{array}$ & $\begin{array}{c}27 \\
119\end{array}$ & $\begin{array}{l}18.5 \\
81.5\end{array}$ \\
\hline $\begin{array}{l}\text { Presence of first aid box in your work space } \\
\text { Yes } \\
\text { No }\end{array}$ & $\begin{array}{c}12 \\
134\end{array}$ & $\begin{array}{c}8.2 \\
91.8\end{array}$ \\
\hline $\begin{array}{l}\text { Use of goggles during filing } \\
\text { Yes } \\
\text { No }\end{array}$ & $\begin{array}{l}77 \\
69 \\
\end{array}$ & $\begin{array}{l}52.7 \\
47.3 \\
\end{array}$ \\
\hline $\begin{array}{l}\text { Practice grade } \\
\text { Good } \\
\text { Fair } \\
\text { Poor }\end{array}$ & $\begin{array}{l}14 \\
80 \\
51\end{array}$ & $\begin{array}{c}9.7 \\
55.2 \\
35.2\end{array}$ \\
\hline
\end{tabular}

Table 7: Relationship Between sociodemographic/occupational data and Knowledge grade.

\begin{tabular}{|c|c|c|c|c|c|c|}
\hline \multicolumn{5}{|c|}{ KNOWLEDGE GRADE } & \multirow[b]{2}{*}{$\chi^{2}$} & \multirow[b]{2}{*}{ p-value } \\
\hline Variables & Good (\%) & Fair (\%) & Poor $(\%)$ & Total $(\%)$ & & \\
\hline $\begin{array}{l}\text { Age Group(years) } \\
10-19 \\
20-29 \\
30-39 \\
40-49\end{array}$ & $\begin{array}{l}0(0.0) \\
8(9.1) \\
0(0.0) \\
0(0.0)\end{array}$ & $\begin{array}{l}28(54.9) \\
49(63.6) \\
12(80.0) \\
2(100.0)\end{array}$ & $\begin{array}{l}23(45.1) \\
21(27.3) \\
3(20.0) \\
0(0.0)\end{array}$ & $\begin{array}{l}51(34.9) \\
77(52.7) \\
15(10.3) \\
2(1.4)\end{array}$ & 12.3661 & 0.0543 \\
\hline $\begin{array}{l}\text { Level of Education } \\
\text { None } \\
\text { Completed Primary } \\
\text { Completed Secondary } \\
\text { Completed Diploma } \\
\text { Bachelor's degree }\end{array}$ & $\begin{array}{l}0(0.0) \\
0(0.0) \\
2(2.8) \\
1(4.8) \\
5(16.7)\end{array}$ & $\begin{array}{l}0(0.0) \\
11(42.3) \\
48(67.6) \\
15(71.4) \\
17(70.8)\end{array}$ & $\begin{array}{l}2(100.0) \\
15(57.7) \\
21(29.6) \\
6(28.6) \\
3(12.5)\end{array}$ & $\begin{array}{l}2(1.4) \\
26(17.8) \\
71(48.6) \\
22(15.1) \\
25(16.4)\end{array}$ & 24.2144 & 0.0071 \\
\hline $\begin{array}{l}\text { Duration of work (years) } \\
<10 \\
>10\end{array}$ & $\begin{array}{l}7(6.3) \\
0(0.0)\end{array}$ & $\begin{array}{l}68(60.7) \\
24(66.7)\end{array}$ & $\begin{array}{l}34(33.0) \\
13(33.3)\end{array}$ & $\begin{array}{l}112(76.7) \\
30(20.5)\end{array}$ & 2.5236 & 0.2831 \\
\hline $\begin{array}{l}\text { Employment pattern } \\
\text { Full time } \\
\text { Part time }\end{array}$ & $\begin{array}{l}4(3.3) \\
3(13.0)\end{array}$ & $\begin{array}{l}80(65.6) \\
12(47.8)\end{array}$ & $\begin{array}{l}38(31.1) \\
9(39.1)\end{array}$ & $\begin{array}{r}122(83.6) \\
24(16.4)\end{array}$ & 5.139 & 0.0752 \\
\hline
\end{tabular}

Table 8: Relationship Between sociodemographic/occupational data and Practice grade.

\begin{tabular}{|c|c|c|c|c|c|}
\hline \multicolumn{5}{|c|}{ PRACTICE GRADE } & \multirow[b]{2}{*}{$\chi^{2}$} \\
\hline Age Group(years) & Good (\%) & Fair (\%) & Poor (\%) & Total & \\
\hline $10-19$ & $3(5.9)$ & $30(58.8)$ & $18(35.3)$ & $51(34.9)$ & 16.1943 \\
\hline $20-29$ & $6(7.8)$ & $39(50.6)$ & $32(41.6)$ & $77(52.7)$ & \\
\hline $30-39$ & $5(33.3)$ & $9.0(60.0)$ & $1.0(6.7)$ & $15(10.3)$ & \\
\hline $40-49$ & $0(0.0)$ & $2.0(100.0)$ & $0(0.0)$ & $2(1.4)$ & \\
\hline \multicolumn{6}{|l|}{ Level of Education } \\
\hline None & $0(0.0)$ & $1(50.0)$ & $1(50.0)$ & $2(1.4)$ & \multirow[t]{5}{*}{8.8358} \\
\hline Completed Primary & $1(3.8)$ & $13(46.2)$ & $13(50.0)$ & $26(17.8)$ & \\
\hline Completed Secondary & $8(11.3)$ & $21(59.2)$ & $21(29.6)$ & $71(48.6)$ & \\
\hline Completed Diploma & $3(14.3)$ & $9(42.9)$ & $10(47.6)$ & $22(15.1)$ & \\
\hline Bachelor's degree & $2(8.3)$ & $16(66.7)$ & $6(25.0)$ & $24(16.4)$ & \\
\hline \multicolumn{6}{|l|}{ Duration of work (years) } \\
\hline$<10$ & $9(8.0)$ & $61(56.3)$ & $39(35.7)$ & $109(74.6)$ & \multirow[t]{2}{*}{5.3922} \\
\hline$>10$ & $5(13.3)$ & $19(50.0)$ & $13(36.7)$ & $37(25.3)$ & \\
\hline \multicolumn{6}{|l|}{ Employment pattern } \\
\hline Full time & $14(11.5)$ & $67(54.9)$ & $41(33.6)$ & $122(83.6)$ & \multirow[t]{2}{*}{3.1845} \\
\hline Part time & $0(0.0)$ & $13(56.5)$ & $10(43.5)$ & $23(15.7)$ & \\
\hline
\end{tabular}


There was a statistically significant relationship between the level of education and their knowledge grade $(\mathrm{P}$ - value of 0.0071) (Table 7). There was also a statistically significant relationship between the age group and their practice grade $(\mathrm{P}-$ value $=0.0127)$. $($ Table 8$)$.

\section{DISCUSSION}

The respondents in this study were relatively young with ages between 13-42 years with a mean age of $24.2 \pm 6.1$ years. This may be due to the fact that it is a timeconsuming occupation since most of the work processes are manually carried out. The paucity of middle aged and elderly people in the profession may be due to the fact that most of the workers leave the trade for other professions/business like driving, real estate with advancing age. Most of the respondents attained secondary level of education. This may be because it serves as a source of income for themselves and their family and also to remain engaged as they wait for resources to further their education. Most of the respondents were single. The mean years the respondents were involved in the occupation from the result obtained was $7.2 \pm 5.8$ years. This may be because they tend to switch to other occupations with time due to the low-income footwear manufacturing generates.

Majority of the respondents have been involved in the occupation between 111 years. Over half of them worked for more than eight hours which is beyond the recommended time for workers according to the International Labour Organization (ILO) and this may be due to the fact that the income they derived was directly proportional to the number of shoes they make which is dependent on the amount of time spent working. Most of the respondents also worked full time.

Most of the respondents were aware of the adverse effect of work on health and knew of hazards associated with their work. The most frequently mentioned included glues $(61.6 \%)$, dust $(87.7 \%)$, Needle prick injuries $(28.1 \%)$. This may be due to the fact that most of the respondent have been involved in the profession for at least a year and may have been informed of the "Dos and Don'ts". This was similar to the findings in a study done in Hazaribagh, Bangladesh among leather workers in which majority were aware of the hazards they were exposed to. ${ }^{9}$ This is however in contrast to another study where majority of work-related injuries were due to lack of awareness of the hazards by the workers ${ }^{9}$

Over two-third of the respondents were not aware of diseases associated with the hazards. This was similar to a study in Bangladesh where 50-60 \% of workplace injuries were due to lack of awareness on the path of the workers. ${ }^{10}$ This may be due to lack of adequate health education since most of them do not go for periodic medical checkups. Most of the respondents were aware of the negative effect of glues and chemicals used during their work process and the positive effect handwashing. Most of the respondents were also aware of the use of PPE during their work process and the importance of regular hospital checkups. Most of the respondents were not aware of standard operating procedures or good ventilation. This may be due to the low socioeconomic factors which influence the construction of their workplaces with many barely having a kiosk for their workplace.

Most of the respondents used face mask during work and practiced handwashing after work. This may be due to the low cost of acquiring the regular face masks. Over two-third of them did not use gloves when working with glues. This is similar to a study carried out in Jaj-mau Kanpur, India in leather processing units which revealed that of all the workers, majority of them did not use gloves during their work thus increasing the risk of skin infection and/or irritation. ${ }^{11}$ Almost all the respondents did not use ear plugs when working on loud machines or use goggles during filing of shoes. Majority of the respondents also did not go for periodic medical checkups in the hospital. 
In this study, factors found to influence the knowledge of safety measures was the level of education. From our study, majority of our respondents attained secondary level of education. Only three of the respondents were even aware of the fact that attending safety training in itself was a safety measure that is useful in the prevention of hazards. This was similar to a study in a footwear industry in Agra India that showed that a large number of the labor force of footwear manufacturing industries were illiterates ${ }^{12}$ and this affected the adoption of new techniques of production. These workers were at a higher risk of work-related hazards.

The practice of safety measures on the other hand was seen to be influenced by the age group. This may be because those involved at earlier ages are not as experienced as those who join at a much more advanced age. This shows a correlation between experience and practice.

It is recommended that continuous educational campaign on workplace hazards, types and proper use of different PPE should be sustained for footwear manufacturers on a regular basis by their association, local and state governments. Safety devices should be made readily available and accessible through sale at subsidized rates to footwear manufacturers by local and state governments. Local and state governments should institute a program that could give financial rewards to Footwear manufacturers who maintain a work-related accident free record yearly.

\section{ACKNOWLEDGEMENTS}

The authors wish to thank all the footwear manufacturers who participated in the study.

YOT, NSO, FKD and OIE were involved in the conceptualization and development of the research protocol for this study.

NSO, FKD and OIE were part of the data collection team analysis
All the authors were involved in drafting of the manuscript.

\section{DECLARATIONS}

Funding: No external funding received for the study

Conflict of interest: None declared

Ethical approval: Approval for the study was obtained from the Health Research Ethical Committee of Jos University Teaching Hospital, (JUTH).

\section{REFERENCES}

1. International Labor Organization (ILO) 2003. Improving safety, health and the working environment in the informal footwear sector. Geneva. ILO [cited 2019, August 19] Available from: www.ilo.org/publns

2. Mansour R, Vajihe H, Mohammad JJ, Hamid S, Parisa A, Seid MA. Evaluation of occupational exposure of shoe makers to benzene and toluene compounds in shoe manufacturing workshops in East Tehran. Journal of National Research Institute of Tuberculosis and Lung Disease. 2012; 11(4): 43-49.

3. Tiwari RR. Child labour in footwear industry:possible occupational health hazards. Indian Journal of Occupational Health and Occupational Medicine 2005;9(1): 7-9.

4. Airsystems-inc. Occupational risk for shoe repairers [internet]. Airsystems-inc;c2019 [updated jan 12019 cited 2019 Aug 18] Available from: http://www.airsystemsinc.com/air-purification-news/airquality/occupational-risk-shoe-repairers/.

5. Amal SA, Mohgah SA, Jihan SH, Wafaa GS, Aya HM. Antioxidants in of shoemakers exposed to organic solvents. Journal of Applied Sciences Research. 2008;4(9): 1107-1117

6. SentryAir. Controlling harmful fumes during shoe repair and leather refinishing[internet].

SentryAir;c2014[updated feb 12014 cited 2019 Aug 27] Available from https://www.sentryair.com/blog/solventfume-control/controlling-harmful-fumesduring-shoe-repair-and-leather-refinishing/.

7. Roquelaure Y, Mariel J, Dano C, Fanello S, Penneau-Fontbonne D. Prevalence, incidence and risk factors of carpal tunnel 
Yetunde Olubusayo Tagurum et.al. Knowledge and practice of safety measures against hazards among footwear manufacturers in Jos, Plateau State.

syndrome in a large footwear factory. Int $\mathrm{J}$ Occup Med Environ Health. 2001;14(4): 357-67. PMID: 11885919.

8. Faremi AF, Ogunfowokan AA, Mbada C, Olatubi IM, Ogungbemi VA. Occupational hazard awareness and safety practices among nigerian sawmill workers. International Journal of Medical Science and Public Health. 2014;3(10):1244-1248

9. Shilpy RB, Ismail R, Abu SB. A study on occupational health and safety practices in Bangladeshi leather industry. Journal of Human Resource and Sustainability Studies. 2019;7: 302-311.

10. Rabiu I, Shakhaoat H, Abu BS. Occupational health hazards and safety practices among the workers of tannery industry in Bangladesh. Jahangirnagar
University Journal of Biological sciences. 2017;6(1): 13-22.

11. Ory FG, Rahmanb FU, Katagade V, Shuklad A, Burdorf A. Respiratory disorders, skin complaints, and low-back trouble among tannery workers in Kanpur, India. American Industrial Hygiene Association journal. 1997;58: 740-746.

12. Jyoti B. A study of labor problems in footwear industry of Agra district \{dissertation\}. Aligarh Muslim University; 2003

How to cite this article: Tagurum YO, Ochekwu IE, Daburuk FK et.al. Knowledge and practice of safety measures against hazards among footwear manufacturers in Jos, Plateau State. Int J Health Sci Res. 2021; 11(4): 157-164. DOI: https://doi.org/10.52403/ijhsr.20210421 